\title{
Preventive Effect of Tephrosia Purpurea Against N,N-Diethylnitrosamine Induced Hepatocellular Carcinoma In Swiss Albino Mice
}

\author{
R. Gnanaraja (Corresponding Author) \\ Department of Biochemistry and Biochemical Engineering \\ SHIATS (Formally Allahabad Agricultural Institute Allahabad) U.P India \\ Tel: 91-896-027-7743Ｅ-mail: rgnanaraja@gmail.com
}

\begin{abstract}
Veeru Prakash
Associate Professor, Department of Biochemistry and Biochemical Engineering SHIATS (Formally Allahabad Agricultural Institute Allahabad) U.P India
\end{abstract}

Tel: 91-983-995-2882Ｅ-mail: veeru_prakash007@yahoo.co.in

Received: January 21, 2014 Accepted: February 3, 2014

doi:10.5296/jbls.v5i2.5276 URL: http://dx.doi.org/10.5296/jbls.v5i2.5276

\begin{abstract}
The aim of the present study is to divulge the preventive nature of Tephrosia purpurea Methanolic Extract (TpME) during DiEthylNitrosAmine (DENA) induced liver cancer in male Swiss albino mice. Anticancer activity of methanolic extract of Tephrosia purpurea was evaluated in DENA induced Swiss albino mice at the doses of 200 and $300 \mathrm{mg} / \mathrm{kg}$ body weight orally and both doses were administered for 14 days. After $24 \mathrm{~h}$ of the last dose, the mice were sacrificed and antitumor effect of TpME was assessed by evaluating liver serum marker enzyme and haematological parameters. Decrease in Aspartate transaminase, Alanine transaminase, Alkaline phosphatase, Bilirubin and Total protein count were observed in TpME treated animals when compared to DENA treated animals. Haematological profiles such as haemoglobin, red blood cell (RBC) and white blood cell (WBC) count reverted to normal level in TpME treated mice. A comparative histopathology study of liver from test group exhibited almost normal architecture, as compared to DENA treated group. The results demonstrated that Tephrosia purpurea methanolic extract at $300 \mathrm{mg} / \mathrm{kg}$ dose exhibits
\end{abstract}


significant antitumor activity than $200 \mathrm{mg} / \mathrm{kg}$.

Keywords: Diethylnitrosamine, Tephrosia purpurea, Liver cancer, Haematology and carcinogenesis

\section{Introduction}

Cancer is a complex genetic disease that is caused primarily by environmental factors. The cancer-causing agents (carcinogens) can be present in food and water, in the air, and in chemicals and sunlight that people are exposed to. The cancer becomes the second major cause of death in the human after cardiovascular disease (Gruddy, 1991). Therefore, there is a continuing search for better control and preventive methods in order to reduce cancer mortality and related side effects. Many investigations are now being carried out to discover naturally occurring compounds, which can suppress or prevent the process of carcinogenesis (Wargovich., et al 1988 and Samaranayake et al., 2000).

Medicinal plants play a significant role in providing primary health care services to rural people. They serve as therapeutic agents as well as important raw materials for the manufacture of traditional and modern medicine. Tephrosia purpurea is a species of flowering plant in the pea family, Fabaceae, that has a pantropical distribution. It is used in the treatment of some major diseases. The antioxidant and anticancer activity of the extracts from medical plants and herbs was associated with their components of phenolic compounds; the major types of phenolic compounds included phenolic acids, flavonoids, tannins, coumarins, lignans, quinones, stilbenes, and curcuminoids (Cai et al., 2004).

In view of this, we have evaluated the preventive effect of TpME against hepatocellular carcinoma in Swiss Albino Mice. The discovery and development of chemotherapeutics that are effective for the treatment and control of liver cancer is urgently needed for present hour.

\section{Material and Methods}

\subsection{Animals}

Male Swiss albino mice strain approximately 8 weeks young mice (weighing approximately 22-25g) were used in this study. The healthy animals were procured from United Institute of Pharmacy, Allahabad, Uttar Pradesh India. The animals were housed in spacious polypropylene cages bedded with rice husk. The animal room was well ventilated and maintained under standard experimental conditions (temperature $27 \pm 2^{\circ} \mathrm{C}$ and 12 hours light / dark cycle) throughout the experimental period. All the animals were fed with standard pellet diet and water ad libitum. The animals were acclimatization to the environment for 7 days prior to experimental use. The experiment was carried out according to the guidelines of the Committee for the Purpose of Control and Supervision of Experiments on Animals (CPCSEA), New Delhi, India.

\subsection{Plant Materials and Preparation of Plant Extract}

The Tephrosia purpurea plant was collected from Yamuna river bank, Allahabad District, in Uttar Pradesh, India. The collected plant materials were washed, sliced and completely dried in 
a hot-air oven at $37^{\circ} \mathrm{C}$. The dried materials was ground into make a fine powder and used for extraction. Two hundred grams $(200 \mathrm{~g})$ of the powered plants were extracted with methanol $(80 \%)$ using "Soxhlet Apparatus" for 48 hours. A semi solid extract was obtained after complete elimination of alcohol under reduced pressure. The extract was stored in refrigerator until used. The extract contains both polar and non-polar phytocomponents. For experiments $200 \mathrm{mg} / \mathrm{kg}$ and $300 \mathrm{mg} / \mathrm{kg}$ body weight of TpME were used. This effective dose was selected based on dose dependent studies of TpME carried out in our laboratory.

\subsection{Experimental Design}

Body weights of the animals were recorded and they were divided into 6 groups. Each group have 6 animals and the details as follow.

\section{Group 1 (Positive Control)}

Normal control mice will be fed with standard diet and served as a control, which received saline.

\section{Group 2 (Negative Control)}

Mice induced with hepatocellular carcinoma by providing DENA $175 \mu \mathrm{l} / \mathrm{kg} / \mathrm{days}$ for a week through intra peritoneal injection

\section{Group 3}

Mice induced with hepatocellular carcinoma by providing DENA $175 \mu \mathrm{l} / \mathrm{kg} /$ day for 7 days through intra peritoneal injection with methanolic extract of Tephrosia purpurea oral gavage daily at the dose of $200 \mathrm{mg} / \mathrm{kg}$ for 14 days.

\section{Group 4}

Mice induced with hepatocellular carcinoma by providing DENA $175 \mu \mathrm{l} / \mathrm{kg} / \mathrm{day}$ for 7 days through intra peritoneal injection with methanolic extract of Tephrosia purpurea oral gavage daily at $300 \mathrm{mg} / \mathrm{kg}$ body weight for 14 days.

\section{Group 5}

Alone methanolic extract of Tephrosia purpurea oral gavage daily at a different dose of 200 $\mathrm{mg} / \mathrm{kg}$ body weight for 14 days.

\section{Group 6}

Alone methanolic extract of Tephrosia purpurea oral gavage daily at a different dose of 300 $\mathrm{mg} / \mathrm{kg}$ body weight for 14 days.

\subsection{Collection of Samples and Hemato \& Biochemical Assay}

On completion of the experimental period, animals were anaesthetized with diethyl either $(2 \mathrm{ml} / \mathrm{kg})$. The blood was collected with and without EDTA as anticoagulant. Blood, plasma for the estimation Hemoglobin (Armour et al., (1965) content, Red blood cell count (Wintrobe et al., (1961) and White blood cells (Dacie and Lewis., (1958) and serum were separated for the 
estimation of various biochemical parameters such as Bilirubin, Asparate amino transaminase (IFCC method., 1986), Alanine amino transaminase (IFCC method., 1986) and Alkaline phosphatase (King and Armstrong., 1934) and Total Protein (Lowry et al., 1951) were determined.

\subsection{Histopathology Studies}

The liver were excised from the experimental animals of each group after collecting the blood sample and washed with normal saline. Initially, the materials were fixed in 10\% neutral formalin solution. Sections were cut using microtome techniques after paraffin embedding. The sections were possessed in alcohol xylene series and were stained with hematoxylin and eosin. The different sections were examined microscopically for the evaluation of histopathological cha nges.

\subsection{Statistical Methods}

All values are expressed as mean \pm SEM. Statistical significance was determined by two-way analysis of variance (ANOVA) and the difference were considered significant at $\mathrm{p}<0.05$ level.

\section{Results}

Recently, the use of some herbs has attracted a great deal of attention as one of the alternative cancer therapies from the point of less toxicity and cost benefits. Therefore, an attempt has been made to evaluate the anticancer activity of methanolic extract of Tephrosia purpurea.

\subsection{Effect of Methanolic Extract of Tephrosia Purpurea on Hematological Parameters}

The hematological parameters of tumor bearing mice were found to be significantly differences compared to the extracts treated groups. In tumor bearing mice it was found that increased in WBC count $(15.1 \pm 0.21)$ and decreased in HB content $(7.78 \pm 0.04)$ with RBC count $\left(2.88 \pm 0.1010^{6}\right)$. The methanolic extract treated group at dose of $200 \mathrm{mg} / \mathrm{kg}$ and $300 \mathrm{mg} / \mathrm{kg}$ body weight restored all the altered hematological parameters to almost near normal (Table 1). All these results suggest the anticancer nature of the extract, the dose of $300 \mathrm{mg} / \mathrm{kg}$ body weight was found to be effective potential than $200 \mathrm{mg} / \mathrm{kg}$ body weight.

Table 1. Effect of methanolic extract of Tephrosia purpurea on the hematological parameters in Swiss albino mice

\begin{tabular}{|l|c|c|c|}
\hline Design of Treatment & Hemoglobin (gm \%) & WBC $\left(10^{3}\right.$ cells $\left./ \mathrm{mm}^{3}\right)$ & $\begin{array}{c}\mathrm{RBC} \\
\left(10^{6} \mathrm{cells} / \mathrm{mm}^{3}\right)\end{array}$ \\
\hline Normal & $13.45 \pm 0.09$ & $8.8 \pm 0.07$ & $5.23 \pm 0.03$ \\
\hline $\begin{array}{l}\text { Tumor Control } \\
\text { DENA }(175 \mathrm{ul} / \mathrm{kg})\end{array}$ & $7.78 \pm 0.04$ & $15.1 \pm 0.21$ & $2.88 \pm 0.10$ \\
\hline $\begin{array}{l}\text { DENA }(175 \mathrm{ul} / \mathrm{kg})+ \\
\text { TPME } 200 \mathrm{mg} / \mathrm{kg}\end{array}$ & $9.38 \pm 0.21^{*}$ & $13.12 \pm 0.15^{*}$ & $3.39 \pm 0.17^{*}$ \\
\hline $\begin{array}{l}\text { DENA }(175 \mathrm{ul} / \mathrm{kg})+ \\
\text { TPME } 300 \mathrm{mg} / \mathrm{kg}\end{array}$ & $11.02 \pm 0.04^{*}$ & $10.31 \pm 0.08^{*}$ & $4.63 \pm 0.06^{*}$ \\
\hline TPME $200 \mathrm{mg} / \mathrm{kg}$ & $13.11 \pm 0.06^{*}$ & $8.67 \pm 0.10^{*}$ & $5.22 \pm 0.02^{*}$ \\
\hline
\end{tabular}




\begin{tabular}{|l|c|c|c|}
\hline TPME $300 \mathrm{mg} / \mathrm{kg}$ & $13.17 \pm 0.04^{*}$ & $8.73 \pm 0.04^{*}$ & $5.29 \pm 0.03^{*}$ \\
\hline
\end{tabular}

Values are expressed as mean S.E.M., $(n=6)$

${ }^{*} \mathrm{P}<0.05$ as compared to tumor control group (Two-way ANOVA).

\subsection{Effect of Methanolic Extract of Tephrosia Purpurea on Liver Enzyme and Histopathology Studies}

The clinical liver parameters of tumor bearing mice were found to be significantly differences compared to the extracts treated groups. In tumor bearing mice it was found that increased in Bilirubin, ALT, AST, ALP and Total Protein. The methanolic extract treated group at dose of $200 \mathrm{mg} / \mathrm{kg}$ and $300 \mathrm{mg} / \mathrm{kg}$ body weight restored all the altered Clinical liver enzymes are almost near normal (Table 2). All these results suggest the anticancer nature of the extract, the dose of $300 \mathrm{mg} / \mathrm{kg}$ body weight was found to be potential activity than $200 \mathrm{mg} / \mathrm{kg}$ body weight. Histopathology study of liver in each group of animals given Fig-1.

Table 2. Effect of methanolic extract of Tephrosia purpurea on the Clinical parameters in Swiss albino mice

\begin{tabular}{|c|c|c|c|c|c|}
\hline Treatments & Billrubin (mg/dl) & ALT (U/L) & AST (U/L) & ALP (U/L) & T. Protein (g/dl) \\
\hline Normal & $0.77 \pm 0.02$ & $37.3 \pm 0.33$ & $32.67 \pm 0.21$ & $74.33 \pm 0.49$ & $7.16 \pm 0.10$ \\
\hline $\begin{array}{c}\text { Tumor Control } \\
\text { DENA (175ul } / \mathrm{kg})\end{array}$ & $1.93 \pm 0.04$ & $100.17 \pm 0.70$ & $91.5 \pm 0.22$ & $188.33 \pm 1.42$ & $9.98 \pm 0.18$ \\
\hline $\begin{array}{c}\text { DENA }(175 \mathrm{ul} / \mathrm{kg})+ \\
\text { TPME } 200 \mathrm{mg} / \mathrm{kg}\end{array}$ & $1.75 \pm 0.03^{*}$ & $86.17 \pm 0.40^{*}$ & $74.5 \pm 0.22^{*}$ & $150 \pm 0.51^{*}$ & $9.13 \pm 0.09^{*}$ \\
\hline $\begin{array}{c}\text { DENA (175ul/kg)+ } \\
\text { TPME 300 mg/kg }\end{array}$ & $1.48 \pm 0.03^{*}$ & $62.5 \pm 0.22^{*}$ & $59.50 \pm 0.22^{*}$ & $135.5 \pm 1.78^{*}$ & $8.32 \pm 0.06^{*}$ \\
\hline $\begin{array}{c}\text { TPME } \\
200 \mathrm{mg} / \mathrm{kg}\end{array}$ & $0.78 \pm 0.02^{*}$ & $37 \pm 0.26^{*}$ & $31.67 \pm 0.21^{*}$ & $72.17 \pm 0.30^{*}$ & $7.17 \pm 0.05^{*}$ \\
\hline $\begin{array}{c}\mathrm{TPME} \\
300 \mathrm{mg} / \mathrm{kg}\end{array}$ & $0.80 \pm 0.02^{*}$ & $34 \pm 0.37^{*}$ & $28.83 \pm 0.17^{*}$ & $62.5 \pm 0.22^{*}$ & $7.48 \pm 0.08^{*}$ \\
\hline
\end{tabular}

Values are expressed as mean S.E.M., $(\mathrm{n}=6)$

${ }^{*} \mathrm{P}<0.05$ as compared to tumor control group (Two-way ANOVA). 


\section{Macrothink}

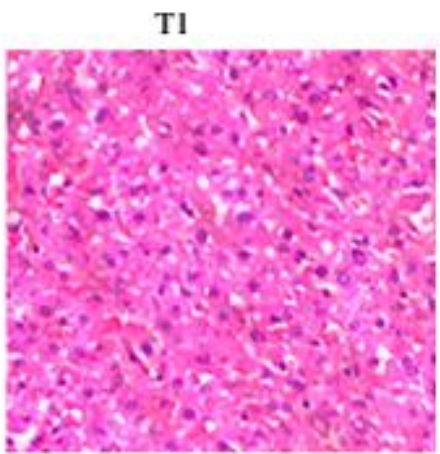

T4

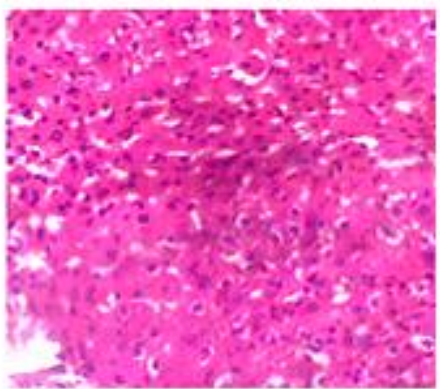

$\mathrm{T} 2$

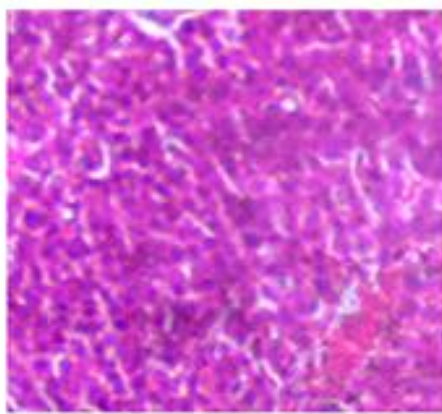

T5

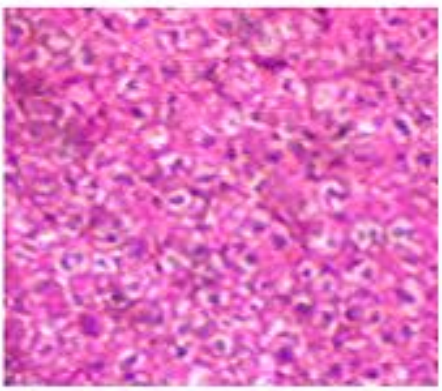

T3

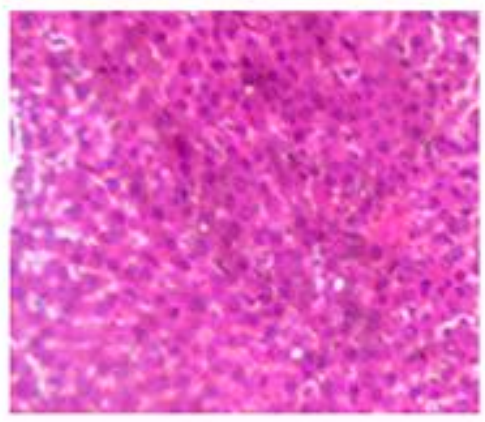

T6

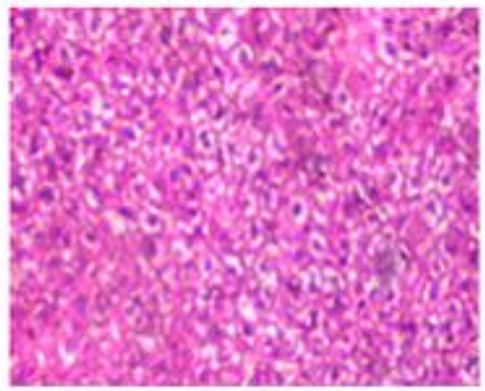

T1- Normal Centrol, T2- DEN Induced Cancer, T3- DEN $+200 \mathrm{mg} / \mathrm{kg}$ TPME, T4- DEN+300mg.kg TPME T5- alone $200 \mathrm{~m}, \mathrm{~kg}$ TPME, T6- alone $300 \mathrm{mg} / \mathrm{kg}$ TPME

Figure 1. photomicrograph of liver (10x) (T1) control group showing normal architecture of liver; T2 animal treated with DENA showing cancer cell developed; (T3) animal treated with DENA+200mg/kg of TPME showing less cancer cell compared to T2; (T4) animal treated with DENA+300mg/kg of TPME showing very less cancer cell compared to cancer control T2; (T5\&T6) animal treated with alone $200 \mathrm{mg} / \mathrm{kg} \& 300 \mathrm{mg} / \mathrm{kg}$ of TPME showing normal architecture of liver compared to T1.

\section{Discussion}

It is well known that liver cancer is one of the most important cancers in the world, resulting in more than 1 million patients and over 260,000 deaths per year (Liu et al., 2006). Therefore, the chemoprevention and treatment of liver cancer is very important. Liver is the major site of metabolism of ingested components; it is highly susceptible to carcinogenic effect. Natural products have long been used to prevent and treat many diseases, including cancer and thus they are good candidates for the development of anti-cancer drugs. The large population use ayurvedic medicine worldwide, there is urgent need for additional, carefully conducted, high quality intensive research to evaluate its efficacy and to develop this discipline to meet ever-new challenges of modern medicine in the field cancer research. Different in vivo and in vitro screening models are available for anticancer activity (Vishal and Thangavel, 2011).

The result of present study showed anticancer effects of TPME leaves against DENA in Swiss albino mice. A significant enhancement of TPME of haemoglobin, red blood cells and decrement of liver marker enzymes and WBC. The proposed study revealed that the fractions 
obtained from TPME plant potent in inhibiting the cancer growth.

Hepatocellular carcinoma is the most frequent primary malignancy of the liver. DENA widely used for studying the mechanism of Hepatocellular carcinoma in animal experimental model (Stelzner, 2006). Tephrosia Purpurea are rich in flavonoid content and the cytotoxic might be due to the presence of flavonoids in the fractions utilized in this study as flavonoids have been shown to possess antimutagenic and antimalignant effect (Hirano et al., 1989; Brown, 1980). The flavonoids have a chemopreventive role in cancer through their effects on signal transduction in cell proliferation and angiogenesis (Osman et al., 2011; Fotis et al., 1997; Weber et al., 1996). Our results suggests that the fractions of extracts obtained in from TPME have good cytotoxic activity against DENA induced liver cancer, which may be attributed to the secondary metabolites and antioxidant of the fractions.

\section{Conclusion}

The methanolic extracts of Tephrosia purpurea showed good potent anticancer activity against n,n-diethylnitrosamine induced hepatocellular carcinoma in Swiss albino. Further studies are in progress in our laboratory in screening of phytochemicals and antioxidant and investigation of molecular mechanisms and responsible for the anticancer activity of this plant. These results will help in the efficient cancer treatments and that would be more beneficial to our social and economic aspects of world.

\section{Acknowledgement}

The authors would like to thank the Sam Higginbottom Institute of Agriculture, Technology and sciences \& United Institute of Pharmacy, Allahabad, India for providing the laboratory facilities to carry out the work.

\section{Reference}

Bergmeyer, H., Bernt, E., Varley, H., Gowenlock, A. H, \& Bell, M. (1980). Practical Clinical Biochemistry, 5th Edn., Willian Heinmann Medical Books Ltd, London; pp 741.

Brown, J. P. (1980). A review of the genetic effect of naturally occurring flavonoids, anthraquinones and related compounds. Mutat Res, 75, 243-247. http://dx.doi.org/10.1016/0165-1110(80)90029-9

Cai, Y., Luo, Q., Sun, M., \& Corke, H. (2004). Antioxidant activity and phenolic compounds of 112 traditional Chinese medicinal plants associated with anticancer. Life Sci, 74, 2157-2184. http://dx.doi.org/10.1016/j.Ifs.2003.09.047

D’Armour F. E., Blood F. R., \& Beldena, D. A. (1965). The manual for laboratory work in mammalian physiology. 3rd ed. Chicago: The University of Chicago Press. p. 4-6.

Dacie, J. V., \& Lewis, S. M. (1958). Practical hematology. 2nd ed. London: J and A Churchill; p. $38-48$.

Fotis, T., Pepper, M. S., Aktas, E., Breit, S., Rasku, S., \& Adlercreutz, H. (1997). Flavonoids, dietary-derived inhibitors of cell proliferation and in vitro angiogenesis. Cancer Res, 57, 
2916-2921.

Gruddy, S. M. (1991). Recent Nutrition Research, implications for foods of the future. Ann Med, 23, 187-193. http://dx.doi.org/10.3109/07853899109148046

Hirano, T. K., Oka, M., \& Akiba, M. (1989). Antiproliferative effect of synthetic and naturally occurring flavonoids on tumour cells of human breast carcinoma cell lines, ZR-75-1. Res Commun Chem Pathol Pharmacol, 64, 69-78.

IFCC methods (1986). The measurement of catalytic concentration of enzymes, J. Clin. Chem. Clin Biochem, 24, 481.

IFCC methods for the measurement of catalytic concentration of enzymes, J. Clin. Chem. Clin Biochem, 24, 494-97.

King, E. J., Armstrong, A. R., \& Harris, R. I. (1934). Phosphatase in obstructive jaundice. Canad. M. A J. J, 31, 14.

Liu, J. G., Zhao, H J., Liu, Y. J., \& Wang, X. L. (2006). Effect of selenium-enriched malt on hepatocarcinogenesis, paraneoplastic syndrome and the hormones regulating blood glucose in rats treated by diethylnitrosamine. Life Sci. 78(20), 2315-2321. http://dx.doi.org/10.1016/j.lfs.2005.09.033

Lowry, O. M., Rosebrough, N. J., Farr, A. L., \& Randall, R. J. L. (1951). Protein measurement with folin phenol reagent. J. Biol. Chem, 193, 265-275.

Osman, M. A., Rashid, M. M., Aziz, M. A., Habib, M. R., \& Karim, M. R. (2011). Inhibition of Ehrlich ascites carcinoma by Manilkara zapota L. stem bark in Swiss albino mice. Asian Pac J Trop Biomed, 1(6), 448-451. http://dx.doi.org/10.1016/S2221-1691(11)60098-1

Samaranayake, M. P., Wickramasinghe, S. N., Angunawela, P., Jayasekara, S., Iwai, S., \& Fukushima, S. (2000). Inhibition of chemically induced liver carcinogenesis in Wistar rats by garlic (Allium sativum). Phytotherapy Research, 14, 1-3. http://dx.doi.org/10.1002/1099-1573(200011)14:7<564::AID-PTR664>3.0.CO;2-Z

Stelzner, F. (2006). (Autoregulatory growth control of a DEN Aomatous polyps and carcinogenesis in the colorectal region. Basics of tumor surgery Part 1). Chirurg, 77, 1048-1055. http://dx.doi.org/10.1007/s00104-006-1258-4

Thirunavukkarasu, C., Premkumar, K., Jagadeeswaran, R., \& Sakthisekaran, D. (2005). The inhibitory effect of sodium selenite on Nnitrosodiethylamine- induced and phenobarbital promoted liver tumourigenesis in rats based on the modulation of polyamine levels. Mol. Cell Biochem, 280(1-2), 165-172. http://dx.doi.org/10.1007/s11010-005-8907-7

Thiruvengadam, D., \& Mangalamani (2011). Daisy Glory, Induction of Hepatic Antioxidant Enzyme by Chrysin in N- Nitrosodiethylamine induced Hepatocellular carcinoma in Wiser albino rats. Int.J. Res. Pharm. Sci, 2(2), 266-271.

Varley, H., Gowenlock, A. H., \& Bell, M. (1980). Practical Clinical Biochemisty, 5th Edn.,William Heinmann Medical Books Ltd, London 1980; 897. 


\section{Macrothink}

Journal of Biology and Life Science

ISSN 2157-6076 2014, Vol. 5, No. 2

Vishal, G, \& Thangavel S. (2011). Anticancer activity of Tephrosia purpurea and Ficus religiosa using MCF 7 cell lines. Asian Pacific Journal of Tropical Medicine, 54, 526-529.

Wargovich, M. J., Woods, C., \& Eng, V. W. S (1988). Chemoprevention of NNitrosomethyl benzyllamine-induced oesophageal cancer in rats by the naturally Cancer thiother, diallyl sulphide. Cancer Res, 48, 6872-6875.

Weber, G., Shen, F., Prajda, N., Yeh, Y. A., \& Yang, H. (1996). Increased signal transduction activity and down regulation in human cancer cells. Anticancer Res, 16, 3271-3282.

Wintrobe, M. M., Lee, G. R., Boggs, D. R., Bithel, T. C., Athens, J. W., \& Foerester (1961). Clinical Hematology 5th ed. Philadelphia;. p. 326.

\section{Copyright Disclaimer}

Copyright reserved by the author(s).

This article is an open-access article distributed under the terms and conditions of the Creative Commons Attribution license (http://creativecommons.org/licenses/by/3.0/). 